\title{
AN E-PORTFOLIO AS EMPOWERING TOOL TO ENHANCE STUDENTS' SELF-DIRECTED LEARNING IN A TEACHER EDUCATION COURSE: A CASE OF A SOUTH AFRICAN UNIVERSITY
}

\author{
M. M. van Wyk \\ Department of Curriculum and Instructional studies \\ University of South Africa \\ Pretoria, South Africa \\ e-mail: vwykmm@unisa.ac.za
}

\section{ABSTRACT}

The purpose of this article is to explore Economics student teachers' views on the usefulness of an ePortfolio as an empowering tool which can enhance self-directed learning in a teacher education course at an open distance learning university. For the sake of this article, an interpretive bricolage research analysis was employed for data collection and a purposive convenient sampling was selected to collect data. Only PGCE (Senior Phase/Further Education and Training) SDECOON students $(n=367)$ which were registered students per module on myUnisa were targeted. Multiple pieces from the ePortfolios that were considered for the purpose of this study were their written assignments for creative writing, a research project, lesson plans, reflective journals entries, podcasts, blog postings, PowerPoint presentations and digital video clippings (DVDs) of classroom lessons. Data were collected and analysed on a weekly basis to create a bricolage of information from the data. Several themes emerged from the bricolage of information and practical implications were highlighted for higher education.

Key words: self-directed learning, reflective journals, ePortfolio, professional development, interpretative bricolage approach, open distance learning

\section{INTRODUCTION}

In order for the higher education sector to be relevant and compatible in this challenging society, universities are compelled to either commit to the process of continuous change, or become redundant (Bates 2010, 15). The current debate at faculties of teacher education around the inclusion of ePortfolios or paper-based portfolios in new or redesigned learning programmes as part of the work integrated learning (WIL) requirement, emerged as an imperative for selfdirected and lifelong learning approaches. The emancipation and transformation of teacher education programmes for a quality education system needs creative and innovative strategies to empower student teachers for the classroom of the future. The ePortfolio is a multi-modal evidence-based strategy currently being introduced to most teacher education programmes at higher education institutions (HEIs) locally and globally (Boulton 2014). In these HEIs, 
ePortfolios are used as an alternative assessment tool for student teacher empowerment, and promotion. Currently, teacher education programmes at institutions of higher learning require prospective student teachers to compile either a paper-based or ePortfolio of evidence as part of a teaching practice qualification (Groom and Maunonen-Eskelinen 2006).

The purpose of this article is to explore Economics student teachers' views on the usefulness of an ePortfolio as an empowering tool which can enhance self-directed learning in a teacher education course at an open distance learning university.

\section{LITERATURE REVIEW}

Literature refers to the concept as digital teaching portfolios (DTPs), or online teaching portfolios (OTP), or electronic portfolios (ePortfolios), but in this article, the term 'ePortfolio' is used throughout. This type of portfolio is gradually being implemented in teacher education programmes, in particular in teaching practice at most institutions of higher education. The compilation of an ePortfolio is undertaken for various reasons and with different objectives, such as assessment and course evaluation. In view of the latter, Bates $(2010,15)$ posited that 'eportfolios enable faculty to see first-hand not only what students are learning, but how they are learning' and added that 'eportfolios also can play a role in assessing the effectiveness of the courses, curricula, and even institutions' $(2010,16)$. Furthermore, research shows that ePortfolio pedagogy can be used as an alternative method of assessment in that it showcases skills and achievements, and reflects and uses appropriate communication modalities (Boulton and Hramiak 2012, 10; Boulton 2014, 375; Groom and Maunonen-Eskelinen 2006, 291; FitzPatrick and Spiller 2010), encourages constructivist and connectivist approaches to teaching and learning (Wray 2007b; Rolheiser and Schwartz 2001, 283), and creates meaningful assessment practices for self-directed learning (Jones 2010, 269; Robichaux and Guarino 2012, 293). Therefore, e-Portfolios are critical instruments for managing each student's academic progress, and can play an important role in managing the performance and progress of an entire education system (Arslam 2014, 132; Fisher, Cheung, Pickard, Chen, Cheung and Wong 2011, 420; Wray 2007a; Trevitt, Macduff and Steed 2013). Moreover, Garrett $(2011,189)$ is of the opinion that ePortfolios provide significant advantages over paper-based alternatives because they are easy accessible online and the end users (learners, educators, parents and school principals) can view ePortfolios on computers, cell phones or other devices. According to these authors, ePortfolios can be accessed by student teachers to issue assignments, and to access assignments through an online platform anytime and anywhere. Furthermore, Chappuis, Stiggins, Arter and Chappuis $(2005,99)$ view e-Portfolios as an effective way of alternative 
assessment in that it encourages students and educators to examine skills that may not be assessable through traditional means, such as higher order thinking, communication and collaborative abilities.

Scholars are of the view that an ePortfolio compiled by student teachers indicates that a student demonstrated knowledge, skills and attitude in compiling specific artefacts for the portfolio (Robichaux and Guarino 2012; Zeichner and Wray 2001). Moreover, Boulton and Hramiak (2012), and several other writers, argue that an ePortfolio is the collection and compilation of evidence in electronic format of work which demonstrates knowledge, skills, attitude and constructive feedback of submitted work of the student teacher (Boulton and Hramiak 2012; Arter and Spandel 1992; Forster and Masters 2010). Research shows that ePortfolios are used in teacher education programmes as an empowerment tool, and a reflection tool. Moreover, Lyons, Hyland, and Ryan $(2002,14)$ state that an ePortfolio is a file of authentic evidence produce by student teachers, indicating what, why and how they learned after compiling the evidence in the ePortfolios. The purpose of an ePortfolio is to showcase a student teacher's personal growth and demonstrate specific knowledge and skills gained during the learning programme. This means that student teachers use the ePortfolio to reflect, engage, collaborate and enhance active, authentic learning. Student teachers develop an ePortfolio for the purpose of self-directed learning (formative assessment), assessment (summative assessment) and employability (Lam 2015). A recent literature review by Bolton (2014) identifies learning, professional development, assessment, job applications, and promotions as key indicators for using ePortfolios. For example, Fisher et al. (2011) investigated the use of digital portfolios at the School for Teacher Education, University of Hong Kong. Findings of the study highlighted that digital portfolios were integrated as part of personal growth to achieve objectives such as the development of personal growth plans, the improvement and acknowledgment of measurable standards, and the creation of self-efficacy among student teachers.

Literature shows that there are several advantages associated with the use of ePortfolios in teacher education programmes, such as the enhancement of lifelong learning, reflective teaching skills, and an increase in pedagogical and technical content knowledge, values, beliefs and positive attitudes, among others (Belgard 2013; Garrett 2011). Throughout the process of collecting, compiling and reflecting on authentic evidence, student teachers are taking ownership of their learning process because they want to produce the best ePortfolio. It is an ultimate goal of any student teacher to reach and record personal goals and achievements during the period of compiling evidence for the ePortfolio. Moreover, Belgard (2013) argues that when 
students compile and share evidence in the ePortfolio, they developing their collaborative skills. Additionally, Wolf and Dietz (1998) mention that the purpose of compiling an ePortfolio is the selection of the best artefacts for a specific purpose as described in a teacher education module or in the instructions for compiling a ePortfolio for assessment purposes. Scholars agree that teachers can share and critique information in the ePortfolio collectively by giving constructive feedback to students regarding the quality and authenticity of evidence produced. Another educational value of an ePortfolio is that student teachers can share information, collaborate to complete group tasks, reflect critically about their writing and critique each other's work in a collegial manner (Robichaux and Guarino 2012; Zeichner and Wray 2001).

\section{THEORETICAL FRAME}

The social networked theory partially underpins this study and is a relatively new phenomenon in teacher education in general, but in open distance learning in particular. This popular social networked paradigm is situated within the social constructivism, sociology and organisational behavioral domains (Uzzi 1996). A social networked theory foregrounds this study because there is a need to examine the views of future teachers of Economics who are studying for a teacher education qualification at an open distance learning institution, on the compilation of evidence in an ePortfolio to enhance self-directed learning. In this particular space specific interrelationships among students are framed. In the context of this study, the researcher explores the concepts of social network theory that underlie the power and popularity of an ePortfolio pedagogy as an e-learning facilitation strategy during teaching practice placements for postgraduate certificate of education students in an ODL context. The researcher is of the opinion that lecturers often see new technologies as threatening their scholarly authority, precisely because these technologies require a re-thinking of roles, but this threat only materialises if we stay locked in a binary framework of lecturer versus student teacher.

This is an overarching concept related to an approach that is oriented to learning and performance achievement. Several theories focuses on numerous learning processes related to outcomes-driven, self-controlled learning behaviour (Zimmerman 2000; Paris and Paris 2001). Knowles (1975), the father of self-regulated learning theory (SRL) or self-directed learning (SDL), defines self-directed learning as 'a process in which individuals take the initiative, with or without the help of others, in diagnosing their learning needs, formulating learning goals, identifying human and material resources for learning, choosing and implementing appropriate learning strategies, and evaluating learning outcomes’ (1975, 15). Moreover, Zuckerman (1995) concurs with Knowles and captures the idea that this phenomenon 'refers to self- 
generated thoughts, feelings, and actions that are planned and cyclically adapted to the attainment of personal goals' $(1995,14)$. There are different views on the concept of selfdirected learning (SDL). Scholars of the SDL view this phenomenon as a process of autonomy of students (Harrison 1978), as a personal attribute (Guglielmino 1977), as a moral, emotional, and intellectual autonomy (Schneckenberg 2010). Emanating from these earlier findings, several frameworks have been emerged to understand SDL models developed by Mocker and Spear's Two Dimensional Model and Garrison's Three Dimensional Model. Paris and Paris (2001) describe the self-regulated learning (SRL) theory as autonomy and control by the individual who monitors, directs, and regulates actions toward the goals of information acquisition, expanding expertise, and self-improvement. As indicated earlier, ePortfolios as an empowering strategy can be used for the enhancement of SDL skills for personal growth and professional development.

Emanating from this context, the following main research question was formulated for the purpose of this study: How are ePortfolios being used in a teacher education course to enhance students’ self-directed learning for them to become competent teachers?

\section{RESEARCH DESIGN AND METHODOLOGY}

Bricolage as research approach was first introduced in the SAGE Handbook of Qualitative Research by Denzin and Lincoln (1999), who adopted Levi-Strauss's bricolage metaphor to describe trends emerging in qualitative research. Denzin and Lincoln propose that 'the combination of multiple methodological practices, and empirical materials, perspectives, and observers in a single study is best understood, as a strategy that adds rigor, breadth, complexity, richness, and depth to any inquiry'. The scholars describe several types of bricolages in their chapter, such as the interpretive bricoleur, a researcher who 'understands that research is an interactive process, shaped by his or her own personal history, biography, gender, social class, race and ethnicity, and by those of the people in the setting' (Denzin and Lincoln 1999, 6). In view of the latter, the researcher decided to employ an interpretative bricolage approach (IBA) to investigate how student teachers understand their experiences with regard to planning, compiling and reflecting on their multiple pieces that are uploaded in the ePortfolio (which is data-driven rather than theory-driven). The phenomenon was therefore explored by means of a bottom-up, inductive approach which aims to explore the meanings that Economics subject student teachers attach to their lived learning experiences (it does not test hypotheses). These student teachers are considered 'lived learning experts with regard to their own learning experiences and can only as themselves tell a better story', and only IBA affords them the 
opportunity to tell their own stories, in their own words, compiling evidence to enhance selfdirected learning (Smith 2010).

The aim of IBA is to negotiate a shared understanding through conversation and intersubjective meaning-making with the PGCE/Bed student teachers, with the primary focus being the student teacher's subjective experience of the use of an ePortfolio as an alternative assessment strategy. IBA is increasingly recognised as a useful tool in health research studies but to a lesser degree pertaining to teacher education research studies. It is the view of this researcher that IBA has the strengths to recognise contextual factors which may influence how individuals are constructing meaning from their own experiences, and as such was thought to be an appropriate method for use within this study. For the collection of data, a purposive convenient sampling was done, namely only PGCE (Senior Phase/Further Education and Training) SDEC00N students $(\mathrm{n}=367)$ which were registered students per module on myUnisa. A quota sampling of ten percent was randomly selected from multiple pieces according to the myUnisa learning management system. For the purpose of this study, the student teachers' multiple pieces from the ePortfolios included two written assignments for creative writing, one individual research project on a specific Economis topic, five lesson plans, reflective journal entries, two podcasts, blog postings, PowerPoint presentations and digital video clippings (DVDs) of classroom lessons. These multiple pieces were counted on myUnisa website as a total number of entries per month. This information was used to explore the content of multiple pieces produced by Postgraduate Certificate in Education (PGCE) in Subject Methodology Economics Education (SDEC00N) student teachers.

Before the study could commence, the researcher applied for ethical clearance and the college ethical clearance committee issued a certificate to conduct research. No names or other identifying details of respondents may be revealed, except for research purposes.

The selected multiple pieces were downloaded, read, evaluated and analysed, and each piece in the ePortfolio was carefully coded. A constant comparison data analysis method was used and different themes were identified. In this case, the researcher and the two research assistants had to piece together different pieces creating a bricolage research collage of information from the data collected. After the completion of the data analysis process, the original pieces were made available to a senior research professor in the department who specialises in qualitative research designs, with a request to validate the trustworthiness and authenticity of content in relation to themes emerged from the analysed data. After three weeks of data validation, she reported that she was satisfied that the correct protocol was followed and thereby validated the process of data collection for this study. All data displayed in this article are inductive and deductive in nature. 


\section{FINDINGS AND DISCUSSIONS}

There are a number of reasons why teacher education programmes are using the ePortfolio increasingly as a driver for professional growth and empowerment.

\section{Growing a teaching philosophy and professional identity}

When planning and presenting lessons on a topic, student teachers are expected to collect, compile and reflect on their own praxis by creating powerful learning environments to accommodate diverse learner populations in their classes. In doing so, student teachers set personal goals and specific objectives to be achieved over time when developing an ePortfolio. Moreover, FitzPatrick and Spiller (2010) posit that the reason for using an ePortfolio in teacher education programmes is to enhance professional identity. In this study, the majority of the student teachers believed and experienced that evidence produced over time negates, as well as enhances, their specific philosophy of teaching. Quinlan (2002) conducted a study on evaluating portfolios for the purpose of promotion in teacher education programmes. Findings revealed that portfolios as a promotional tool provide insightful information regarding student teachers' teaching philosophy, professional development, teaching methods, and career pathing. Moreover, Garrett $(2011,189)$ and Arslam (2014) argue that ePortfolios can be used as a means to enhance a student's professional identity and personality. This student stated her teaching philosophy as follows: 'It is easy to talk about what, why, when and how regarding enhancing your teaching philosophy, but when you start reflecting about your daily teaching and learning, you want to make an educational contribution as a change agent in the lives of those entrusted in your care’. Another study conducted by Schonwetter, Sokal, Friesen and Taylor (2002) revealed how students develop teaching philosophies at institutions of higher learning. The authors made a valuable epistemological contribution to a conceptual model for the development of teaching philosophy statements for student teachers, which could be used to enhance this phenomenon in teacher education programmes. Another female student responded to the issue of teaching philosophy: 'My philosophy of teaching is embedded in the notion of gratitude. I am grateful and thankful for starting my career as student teacher on how to support my learners to become good citizens one day. For me teaching is a calling and that's why I choose to become a professional.’

Another student said: 'My ePortfolio helps me to grow my philosophy and it is an effective learning tool in supporting my personal growth and the development of professional practice becoming a professional. I love my subject and teaching children.’ 


\section{Applying Economics CAPS content knowledge for transformative learning}

Literature indicates that ePortfolios can be used as a means to reveal the student teacher's personal values and intended goal, and to formulate a vision to be achieved overtime. Garrett (2011, 190) views the developing of the ePortfolio over time as a transformative learning process, entailing three distinctive issues: the use of metacognitive learning strategies, the engagement of diverse approaches, and the evaluation of their own learning process. The author is of the view that compiling the evidence shows that transformative learning is taking place continuously which is helping student teachers to share evidence with other students, expressing their ideas for self-enrichment and self-efficacy. One student had the following to say about using subject content knowledge:

My mentor teacher at my placement school was supportive by helping to use CAPS, plan my lessons. Over the teaching practice sessions I had the opportunity to teach my lessons and learn how important it is to plan good lessons and prepare my topics in advance, any topic. We learned how to use CAPS and develop lessons. This was a huge learning experience starting at the beginning of the year and completing my teaching practice. I have learned how to teach the subject. I feel confident to do an efficient job.

Lim and Lee (2014) posit that it is important that faculties must support students during their initial teacher education programmes. Students reported that the best part of receiving continual support and monitoring from mentors during their school placements was the constructive feedback and exchange of insights on teaching the subject. There was sufficient time for exchanging ideas in order to improve the lessons presented before, during and after the ten weeks' teaching practice placements. These sentiments were echoed by one of the students in the blog postings:

In our one on one session with my mentor teacher at my placement school, I received very helpful and constructive feedback on my lesson presentations during the ten week teaching practice. This empowered me to grow and become more effective in my teaching. I really enjoyed and loved the idea of exchanging insights of teaching the subject, especially in relation to the CAPS curriculum for Economics.

Students' multiple pieces indicated that it encouraged the integration of personal, peer and expert views on how to build relationships with others, support one another and give advice during teaching practice. Students remarked that they were learning to teach Economics education in a real, practical manner. Emanating from these sentiments, the evidence provided in the ePortfolio shows the identities of the student teachers, demonstrating each student teacher's knowledge and skills, and evidence of authentic artefacts compiled over a period of learning. Most student teachers display their learning process and experiences through their 
ePortfolios. This is the view of one of the students:

I appreciated the fact that all of us during our school visits and placements ... really learnt how to teach the subject. I decided to live my teacher vision to achieve specific outcomes for my teaching practice. I really enjoyed the ten weeks at the school where I was placed. It was the real thing in practice. You felt that the real journey as a professional had been started. It was an eye-opener to stand in front of grade 11 classes. I was scared at the beginning but after spending time in a real classroom on how to teach Economics as a school subject, I was really delighted and satisfied with the real life experience. This makes it special to me.

Student teachers thought that it prepared them to be effective self-assessors: 'For me, my regular and constructive feedback received was significantly beneficial and helped monitoring my teaching and my classroom progress. It offers me an assessment-feedback.'

In this module course, students use the Economics CAPS policy (Department of Basic Education, 2011) and study guide for preparing their lesson plans. To pass this module course, it is required and expected students that students must demonstrate sound subject content knowledge to become subject specialists. Furthermore, scholars of ePortfolios concur with the latter view that peer discussion of ePortfolios creates excellent opportunities for authentic learning as a critical endeavour for transformative learning (Fisher et al. 2011; FitzPatrick and Spiller 2010).

\section{Developing reflective capacity and teaching reflective practices}

Research studies revealed that ePortfolios support student teachers by creating learning opportunities to make a connection between theory and practice (Hoekstra, Jocelyn and Crocker 2015; Boulton and Hramiak 2012; Ndamba 2007). Boulton (2014) conducted a study on the use of ePortfolios beyond pre-service teacher education. Findings revealed that ePortfolios were being used for alternative assessment, enhancing authentic, self-directed learning (lifelong learning and life wide learning) and promoting student self-reflection. When compiling evidence in the ePortfolio, student teachers first reflect and then make inform decisions about what they want to include as quality evidence in their ePortfolios. Dyment and O'Connell (2011) conducted a study on the quality of reflection in student journals and found that the levels of reflection in student portfolios were not that high. On the other hand, in this study most students reflect consistently on comments and remarks in their reflective journals.

Literature shows that there are several advantages for using ePortfolios in teacher education programmes. These advantages are enhanced lifelong learning, reflective teaching skills, increased pedagogical and technical content knowledge, values, beliefs, and positive attitudes, amongst others (Onks 2009; Minott 2008; Groom and Maunonen-Eskelinen 2006; 
Schonwetter et al. 2002). Throughout the process of collecting, compiling and reflecting on authentic evidence, student teachers are taking ownership of their learning process because they want to produce the best ePortfolios. The reflective journal entries required students to reflect on their teaching sessions in subject practice, which they found to be beneficial.

One female student teacher said: 'I was forced to rethink how I will teach a specific topic to a large class. This means I have to plan and decide how I will approach my class. So I was forced to reflect on my objectives to be achieved ... no doubt it forces me to budget for time out, to stop and think of how I will approach my next lesson.’

This is an excellent way to reflect on praxis. Reflection is important for successful learning and a teacher is always a reflector - reimaging his or her teaching daily. Belgard (2013) as well as Jones (2010) indicated that reflection remains a crucial part of the repertoire of a good teacher, and student teachers can develop this skill by consistently reflecting on their teaching practice sessions before, during and after they plan, develop and present evidence for the ePortfolio. For this study, reflective journal entries required student teachers to reflect on their teaching sessions in subject practice, which they found to be beneficial.

In the next extract, this student teacher wrote in her reflective journal entry: 'I think it is a mirror of my performance which gives me a clear picture of what happened on my teaching day. Therefore, I could reflect on my classroom experiences. It helps me modify my teaching practice.’

In conclusion, scholars agreed that student teachers must have opportunities to reflect in planning, and compiling the ePortfolio. The purpose of compiling the ePortfolio is to enable student teachers to rethink and critically reflect on their practice while becoming a professional (Zeichner and Wray 2001; Dutt-Donter and Gilman 1998).

\section{Applying ICT, different types of technical pedagogical content knowledge (TPCK) and other technologies}

In the last decade, teachers have become exposed to more technologies that impact class environments, teaching methods, strategies and techniques in the classroom. This technological change compels teachers to have a solid understanding of digital pedagogy, or technical pedagogical content knowledge (TPCK). A study conducted by Condy, Chigona, Gachago and Ivala (2012, 34) reported that most teachers lack TPCK competencies and recommended they be 'equipped with technological pedagogical skills which will enable them to competently integrate the new technologies in their teaching and learning'. A competent teacher will ultimately create powerful learning environments for optimal learning experiences for the 
learners. With these technologies at their disposal, teachers can now more than ever create powerful learning spaces to accommodate the diverse learning styles of the digitally-oriented youth. Teachers can create and employ innovative, different types of TPCK and other technologies. Scholars are of the view that teachers must be equipped to plan, design and use information technologies at maximum level in education in the digital age to increase the interest and attendance of students, and to achieve student learning outcomes (Belgard 2013; Seldin, Miller and Seldin 2010). With reference to this study, in most cases students use metacognitive strategies to produce quality authentic multiple pieces and artefacts for their ePortfolios. Furthermore, it was clear that there are specific reasons why teacher education programmes force student teachers to plan and compile an ePortfolio.

One student indicated that 'compiling evidence for my ePortfolio, I have the chance to using different types of social media tools and other ICT tools such our blog, podcasts, PowerPoint presentations and e-discussion forum. We were exposed to different kinds of ICT and other technologies in our learning unit. After submitting eight activities into the ePortfolio, I reflected on them and my lecturer gave constant constructive feedback.'

The $21^{\text {st }}$ century came with possibilities and opportunities for using ICT in the classroom, especially Web 2.0 technologies. Schools and in particular the Economics teacher have been exposed through different media, for example TV, DVDs and film, to advanced education locally and globally. Van Wyk $(2014,371)$ is of the view that using social media to support educational endeavours will align the benefits of in-person learning communities with the benefits of using technology to support student engagement. During the eDiscussion forums students started a WhatsApp group on subject-related matters.

One student posted the following on the blog: 'My WhatsApp group really helped me to plan lessons on challenging topics such as poverty and business cycles. On the WhatsApp group we were brainstorming ideas, sharing and communicating.'

Students also start to use social media platforms to connect and communicate and a student commented on the ICT programme for tracking plagiarism: 'We were also provided with an article on plagiarism. It also made clear to us that all submitted evidence produced by students will be put through a plagiarism detecting programme.'

Students were warned not to cut and paste from others' work without acknowledgement. The activities are put through a plagiarism detection program, the Turnitin similarity test, which checks student teachers' assignments for possible plagiarism. This process helps students to improve their writing skills and is not judgmental, but rather developmental in nature. As a category, the analysis revealed that the ePortfolio activities were viewed as a successful 
monitoring and assessment method. A student responds:

Subsequently, I can read back over my experiences and observe my progress critically. This rereading could help me deepen my understanding of learning to teach purposefully as well as avoid the mistakes. I used blogs postings and reflective journal entries in all my other related activities as a method of assessing my professional development. It serves as valuable feedback on all of my teaching experiences.

The learning unit 'ICT and social media in the classroom' in the Study Guide for SDECOON encourages student teachers to explore these technologies during the teaching practice sessions. Students are compelled to employ ICT and other technologies in their teaching plans. During teaching practice assessment visits by faculty lecturers, these students must show planning for and use of ICT in their lesson plans. Seldin, Miller and Seldin (2010) concurred that the teaching portfolio is an important piece of evidence that shows improved teaching performance and can be used for promotional purposes. It seems that students are using ICT and social media platforms such as Facebook and WhatsApp as teaching and learning e-tools to support learners.

\section{Personal values and socialisation with mentor teachers and fellow students}

On the eDiscussion forums many students indicated that they shared information about good teaching practices. They also mentioned that collaboration and social interaction led to the development of positive relationships. Scholars are of the view it is critical for student teachers to reflect on their practices (Wray 2007a; Bates 2010; Ruys, Van Keer and Aelterman 2012). The latter argues that, to build good classroom relationships between student teachers, electronic forums could be used as a starting point, but also to promote on-going dialogical opportunities, and further collaboration among student teachers (Engin 2013; Arslam 2014; Groom and Maunonen-Eskelinen 2006; Xu 2003). One student teacher responded:

I realised how effective and helpful in terms of my self-development the ePortfolio is, because I could see myself as learner and teacher. It is completely different ... it helps me promote a selfexploration of my personal views about learning and Economics teaching. These views will exceptionally affect my personality. It made me strong and proud of myself. I have learned a lot about myself and how to develop an ePortfolio. Most of the eight activities in the ePortfolio have definitely developed my level of self-confidence. It enabled me to document my own professional development .... Writing about my professional practice helped in promoting my personal values. To be serious, honest, industrious, cooperative, faithful, determined.

Some student teachers stated that they were able to build up trust in the group, although there were a few students who avoided making 'deep’ comments and kept things very superficial. One of them stated: 
Your reflective journal is a personal endeavour, a real experience over time in a classroom. A personal journey to be more sensitive to learners' needs as well your own shortcomings. We during this course tried very hard to build good relationships through trust, collaboration and social interaction, either as students or between learners and teacher mentors. You write this personal stuff in your own journal - you tended to focus on more professional vs. personal stuff. I love people and that's why I have chosen teaching as a career. I love to socialise and work together with other people.

A few students felt that they had come to trust each other during the course and that this naturally flowed into the group eDiscussion forums. Most of the reflective journal entries suggest that students consider the building of good relationships through collaboration and social interaction to be a very important attribute of a professional teacher, as it encourages social interaction and collaboration amongst student teachers.

\section{Using different student-centred methods and techniques}

Literature indicates that ePortfolio is an effective e-learning tool for improving the ability of student teachers to become professionals. Scholars are of the view that teaching portfolios permit students to file and share their teaching and learning practices, reflect on their pedagogical practices, engage in ongoing dialogues with fellow students, improve their teaching, and showcase their professional capacity for appraisal, promotion and job search (Barrett and Carney 2005; Seldin et al. 2010; Wright, Knight and Pomerleau 1999). Student teachers emphasised that eDiscussion forums, blogs and reflective journal writing helped them to select teaching methods and strategies for specific lessons. One student replied in his reflective journal:

You need to plan carefully what and how to apply your teaching methods, especially when you teach large classes. What the curriculum policy indicated is totally different from the real classroom situation. During my teaching practice weeks, I have learned new things in a real classroom situation. Every class is different. So your teaching approach is also different. Most of my classes I implement the student-centred approach. There is no one size fits all because you deal with diverse learning contexts. This is authentic learning at its best.

Another student responds as follows in the eDiscussion forum entries:

In our study guide there are different teaching approaches. During my school placement, I started to experiment with the think-pair-share teaching technique as explained in our study guide. After using it in my class, it gave me a new perspective about how learners learn. When I planned my lesson on business cycles for grade 10, I grouped learners in the think-pair-share technique. I explained to them the reasons for using this technique. I instructed learners first to read the article on business cycles individually and then group to share what they read with their partner. Lastly, each small group presented their ideas to the rest of the class for further comments. This was really fun and I realised the importance of student-centred approaches for teaching the subject. 
Most students revealed that they were using different student-centred methods and techniques in planning Economics lessons. This is what one student wrote in the blog posting: 'For most of my lessons I carefully planned active participative learning environments. I want my learners to participate in my classroom activities. One particular learner-centred approach I really like is the teams-games-tournaments method. This method is where learners are grouped as a team to play an Economics game. Each group named their own team. Most teams preferred soccer team names and specific players such as Manchester United, Barcelona, Real Madrid, Chelsea, Liverpool etc.'

Different teaching approaches, such as teacher- and learner-centred approaches, are discussed in the SDEC00N module study guide. Student teachers can experiment with these approaches during their school placements. Judging by the responses in the reflective journal entries, eDiscussion postings and blog postings, it seems that the majority of students experimented with different student-centred methods and techniques.

\section{CONCLUSION AND IMPLICATION}

In this article I have sought to outline how the use of ePortfolios is empowering and an attractive way of fostering self-directed learning and providing evidence of achievement for warranting purposes, particularly in the context of a teacher education course at an open distance learning university. From the ePortfolio data analysis it appears that self-directed learning occurs through self-appraisal by student teachers reflecting on their personal values, learning styles and strategies of learning, all in order to enhance self-efficacy. Second, regarding the compilation of artefacts for the ePortfolio, important self-management skills were developed, namely formulating specific goals and short-term objectives, and setting high standards to achieve excellent results or performance in the course. Lastly, in the reflective journals the students showed increased self-reflection on artefacts by self-assessing these against sets of assessment criteria. The assessment of submitted evidence indicated whether self-directed learning took place. The bricolage of evidence produced by student teachers indicated that ePortfolios as an empowering tool enhanced students' self-directed development into competent teachers who are well-grounded in the knowledge, skills, values, principles, methods and procedures relevant to teaching Economics in Further Education and Training phase. The ultimate purpose of this study was to show that student teachers were empowered by this module course, growing a teaching philosophy and professional identity. According to the majority of student teachers they love to teach children and have developed into subject specialists that can teach in any context. 
Findings further reveal that students applied sound subject content knowledge during the teaching practice sessions. Specific lesson plans with applicable activities were provided as evidence in most of the submitted ePortfolios. With reference to the matter of reflection, it emerged that most students took time out to reflect on what, how and why they compiled evidence in their ePortfolios. This is an important aspect of a teacher's self-directed learning process on the way to becoming a professional. Reflecting is an enabling means for student teachers to ponder and critically reflect on their practice. Student teachers demonstrated that they explored ICT and other relevant Web 2.0 technologies (social media tools) during the teaching practice sessions. It was evident that student teachers, mentor teachers and learners built good relationships and became involved in social interaction over the course of these placement periods. Furthermore, student teachers implemented different types of teacher and learner-centred teaching approaches, but preferring and mostly using student-centred methods and techniques, such as cooperative learning techniques. The findings of this investigation could not be generalised because only a small sampling was employed in a teacher education course.

Ultimately, the findings of this study propelled several implications for using ePortfolios as driver for an alternative assessment strategy at institutions of higher education, in particular teacher education programes. It is therefore clear to formulating intended outcomes pertaining to the scope, purpose and objectives for using and implementing an ePortfolio pedagogical approach for teacher education. To do this, faculties are compelled to provide consistent, ongoing feedback and monitoring on required tasks to compile ePortfolio evidence. With reference to teacher education progammes, ePortfolios must not be seen as 'nice-to-have' idea but be used as an integrated technology and pedagogy approach as vital components for the successful implementation of the ePortfolio as an alternative assessment strategy in student teacher empowerment. It is therefore of vital importance that faculties at higher education should debate the merit of the inclusion of ePortfolios as part of the work integrated learning requirement for certain learning programmes. Additionally, ePortfolios can be used on different face-to-face or online platforms which may have serious cost-implications because online platforms could very expensive to be host (e.g. Mahara online platform). To implement ePortfolios successfully, there will be financial implications as well rethinking of curriculum evaluation for higher education institutions which could be an expensive exercise in the current climate on 'fees-must-fall' outcry. Moreover, higher education institutions must implement a mentor-student teacher approach to support students to build good relationships as means as part of ePortfolio development. Finally, higher education institutions must formulating clear 
assessment criteria for evaluating ePortfolios as an alternative assessment strategy against programme requirements.

\section{ACKNOWLEDGEMENT}

The author is indebted to the critical reviewers for constructive feedback and positive comments. Acknowledgement is given to the Economics student teachers who voluntarily participated in this research study. The quality of language revision work done by the University’s Language Services is highly appreciated. Lastly, any opinions, findings and conclusions expressed in this paper are those of the author and do not reflect the views of the Department.

\section{REFERENCES}

Arslam, R. S. 2014. Integrating feedback into prospective English Language Teachers' writing process via blogs and portfolios. The Turkish Online Journal of Educational Technology 13(1): 131-150.

Arter, J. and V. Spandel. 1992. Using portfolios of student work in instruction and assessment. Educational Measurement Issues and Practice Spring: 36-44.

Barrett, H. and J. Carney. 2005. Conflicting paradigms and competing purposes in electronic portfolio development. TaskStream web site.

Bates, T. 2010. New challenges for universities: Why they must change. In Changing cultures in higher education: Moving ahead to future learning, ed. U. D. Elhers and D. Schneckenberg. Berlin: Springer.

Belgard, S. F. 2013. Portfolios and e-portfolios: Student reflection, self-assessment, and goal setting in the learning process. In Sage handbook of research on classroom assessment, ed. J. H. McMillan, 331-346. Thousand Oaks, CA: Sage Publications.

Boulton H. 2014. ePortfolios beyond pre-service teacher education: a new dawn? European Journal of Teacher Education 37(3): 374-389. http://dx.doi.org/10.1080/02619768.2013.870994 (accessed 12 January 2016).

Boulton, H. and A. Hramiak. 2012. 'E-Flection: The development of reflective communities of learning for trainee teachers through the use of shared online web logs.' Reflective Practice: International and Multidisciplinary Perspectives, 1-13. http://dx.doi.org/10.1080/14623943.2012.670619 (accessed 28 March 2015).

Chappuis, S., R. Stiggins, J. A. Arter and J. Chappuis. 2005. Assessment for learning: An action guide for school leaders, 99. Portland, Ore: ETS Assessment Training Institute.

Condy, J., A. Chigona, D. Gachago and E. Ivala. 2012. Pre-service students' perceptions and experiences of digital storytelling in diverse classrooms. The Turkish Online Journal of Educational Technology 11(3): 278-285.

Denzin, N. K., and Y. S. Lincoln. (Eds.). 1999. The SAGE handbook of qualitative research. 3rd Edition. Thousand Oaks, CA: Sage Publications.

Department of Basic Education. 2011. National Curriculum and Assessment Policy Statements (CAPS) for Economics Grade 10-12. Government Printers, Gazette No. 34600: Pretoria.

Dutt-Donter, K. and D. A. Gilman. 1998. Students react to portfolio assessment. Contemporary Education 69(3): 59-65.

Dyment, J. E. and T. S. O’Connell. 2011. Assessing the quality of reflection in student journals: A review of the research. Teaching in Higher Education 16(1): 81-97. 
doi:10.1080/13562517.2010.507308

Engin, M. 2013. Questioning to scaffold: an exploration of questions in pre-service teacher training feedback sessions. European Journal of Teacher Education 36(1): 39-54.

FitzPatrick, M. A. and D. Spiller. 2010. The teaching portfolio: Institutional imperative or teacher's personal journey? Higher Education Research and Development 29(2): 167-178.

Fisher, D., H. Cheung, V. Pickard, J. Chen, T. Cheung and A. Wong. 2011. Integrating ePortfolios into teaching and learning: 10 CityU case studies. Hong Kong S.A.R.: City University of Hong Kong. http://www.cityu.edu.hk/edge/eportfolio/ (accessed 14 January 2015).

Forster, M. and G. Masters. 2010. Progression and assessment: Developmental assessment. In International Encyclopedia of Education, ed. P. Peterson, E. Baker and B. McGaw, 231-243. 3rd Edition. Chatswood, NSW: Elsevier.

Garrett, N. 2011. An e-portfolio design supporting ownership, social learning, and ease of use. Educational Technology \& Society 14(1): 187-202.

Groom, B. and I. Maunonen-Eskelinen. 2006. The use of portfolios to develop reflective practice in teacher training: A comparative and collaborative approach between two teacher training providers in the UK and Finland. Teaching in Higher Education 11(3): 291-300.

Guglielmino, L. M. 1977. Development of the self-directed learning readiness scale. Unpublished doctoral dissertation, University of Georgia, Athens.

Harrison, R. 1978. How to design and conduct self-directed learning experiences. Group and Organization Studies 3(2): 149-167.

Hoekstra, A., R. Jocelyn and J. R. Crocker. 2015. Design, implementation, and evaluation of an ePortfolio approach to support faculty development in vocational education. Studies in Educational Evaluation 46: 61-73. http://dx.doi.org/10.1016/j.stueduc.2015.03.007

Jones, E. 2010. Personal theory and reflection in a professional practice portfolio. Assessment \& Evaluation in Higher Education 35(6): 699-710.

Knowles, M. 1975. Self-directed learning. Chicago: Follet.

Lam, R. 2015. Assessment as learning: Examining a cycle of teaching, learning, and assessment of writing in the portfolio-based classroom. Studies in Higher Education http://dx.doi.org/10.1080/03075079.2014.999317 (accessed 5 August 2015).

Lim, C. P. and J. C. K. Lee. 2014. Teaching e-portfolios and the development of professional learning communities (PLCs) in higher education institutions. Internet and Higher Education 20: 57-59. doi:10.1016/j.iheduc.2013.10.002

Lyons, N. 1998. With portfolio in hand. Validating the new teacher professionalism. New York: Teachers College Press.

Lyons, N., A. Hyland and N. Ryan. 2002 Advancing the scholarship of teaching and learning through a reflective portfolio process: The University College Cork experience. Cork: University College Cork.

Minott, M. A. 2008. Vally's typology of reflection and the analysis of pre-service teachers' reflective journals. Australian Journal of Teacher Education 33(5): 55-64.

Ndamba, G. T. 2007. Reflective skills: Students' use of their evaluation of teaching. An action research based teaching practice supervision portfolio submitted to the University of Zimbabwe. Zimbabwe Bulletin of Teacher Education 14(1): 58-78.

Onks, S. C. 2009. Collaborative reflective practice of two early childhood educators: The impact on their ongoing inquiry and professional development. Doctoral Dissertation, University of Tennessee.

Paris, S. C. and A. H. Paris. 2001. Classroom applications of research on self-regulated learning. Educational Psychologist 36(2): 89-101.

Quinlan, K. M. 2002. Inside the peer review process: How academics review a colleague's teaching 
portfolio. Teaching and Teacher Education 18(8): 1035-1049.

Robichaux, R. R. and A. J. Guarino. 2012. The impact of implementing a portfolio assessment system on pre-service teachers' daily teaching reflections on improvement, performance and professionalism. Creative Education 3(3): 290-292.

Ruys, I., H. van Keer and A. Aelterman. 2012. Examining pre-service teacher competence in lesson planning pertaining to collaborative learning. Journal of Curriculum Studies 44(3): 349-379.

Rolheiser, C. and S. Schwartz. 2001. Pre-service portfolios: A base for professional growth. Canadian Journal of Education 26(3): 283-300.

Schneckenberg, D. 2010. Overcoming barriers for eLearning in universities - portfolio models for eCompetence development of faculty. British Journal of Educational Technology 41(6): 979-991. doi:10.1111/j.1467-8535.2009.01046.x

Schonwetter, D. T., L. Sokal, M. Friesen and K. L. Taylor. 2002. Teaching philosophies reconsidered: A conceptual model for the development of teaching philosophy statements. The International Journal for Academic Development 7(1): 83-97.

Seldin, P., J. E. Miller and C. A. Seldin. 2010. The teaching portfolio: A practical guide to improved performance and promotion/tenure decisions. 4th Edition. San Francisco, CA: Jossey-Bass.

Smith, J. 2010. Interpretative phenomenological analysis: A reply to Amedeo Giorgi. Existential Analysis 21(2): 186-192.

Trevitt, C., A. Macduff and A. Steed. 2013. [e] portfolios for learning as evidence of achievement: Scoping the academic practice development agenda ahead. The Internet and Higher Education 20: 69-78.

Van Wyk, M. M. 2014. Using social media in an Open Distance Learning Teaching Practice Course. Mediterranean Journal of Social Sciences 5(1): 370-377.

Wright, W. A., P. T. Knight and N. Pomerleau. 1999. Portfolio people: Teaching and learning dossiers and innovation in higher education. Innovative Higher Education 24: 89. doi:10.1023/B:IHIE.0000008148.71650.e6

Wolf, K. and M. Dietz. 1998. Teaching portfolios: Purposes and possibilities. Teacher Education Quarterly Winter: 9-22.

Wray, S. 2007a. Teaching portfolios, community, and pre-service teachers' professional development. Teaching and Teacher Education 23: 1139-1152.

Wray, S. 2007b. Supporting teacher candidates during the electronic portfolio development process. ELearning and Digital Media 4(4): 454-463.

Uzzi, B. 1996. 'The sources and consequences of embeddedness for the economic performance of organizations: The network effect'. American Sociological Review 61(4): 674-698.

$\mathrm{Xu}, \mathrm{J}$. 2003. Promoting school-centered professional development through teaching portfolios. Journal of Teacher Education 54(4): 347-361.

Zeichner, K. and S. Wray. 2001. The teaching portfolio in US teacher education programs: What we know and what we need to know. Teaching and Teacher Education 17(5): 613-621. doi:10.1016/S0742-051X(01)00017-8

Zimmerman, B. J. 2000. Attaining self-regulation: A social cognitive perspective. In Handbook of selfregulation, ed. M. Boekaerts, P. R. Pintrich and M. Zeidner, 13-39. San Diego, CA: Academic Press.

Zuckerman, J. T. 1995. Using journal writing in a graduate science education course to promote constructivist pedagogy. Journal of Science Teacher Education 1: 53-56. 